\title{
The Role of Gender in Language Communication: A Short Overview
}

\author{
Dorota Brzozowska \\ Institute of Polish Language, University of Opole \\ ul. Oleska 48, 45-052 Opole, POLAND
}

dbrzozowska@uni.opole.pl

\begin{abstract}
The paper deals with the development of the gender concept and the way it is moving away from the notions of binary thinking. Its influence on the methods of linguistic analysis is taken into consideration. Different feminist ideologies - liberal, radical, socialist and cultural feminism as well as the feminism of power - are presented in the context of their view on women-men relations. Other ideologies that shape the idea of 'doing gender' are shown, too. All of them - postmodernism, identity politics and the globalization trend - come from outside linguistics. The binary classification is usually made automatically as an obvious and natural one. It is done against a strong tendency to underline the fuzziness of male-female boundaries in the philosophical speculations that are a starting point for the research in many disciplines.
\end{abstract}

The development of the 'gender' concept and the way it is moving away from the notions of binary thinking are interesting issues that influence the methods of linguistic analysis to a great extent. The aim of this paper is to answer three main questions: What has influenced the ideological movement? How is the change reflected in the research? What are the perspectives of this type of thinking?

Since the gender discussion could be traced back to feminist debates, it is worth looking at different feminist ideologies and their point of view on the women-men relations. The main ideologies are named liberal feminism, radical, socialist and cultural feminism as well as the feminism of power (Ślęczka 1999).

The liberal feminism underlines the gendered division of social roles as a cause of unequal salaries. Both sexes accept this status quo - men, as it is beneficial for them and women as they are under the pressure of stereotypes that their place is at home. The situation is a source of frustrations for those men who would like to stay at home and for those women who would rather pursue their professional careers. The solution would be an equal treatment of both sexes enabling the free choice of the roles. The main result of educational deeds should be a situation when gender is socially transparent, unnoticeable and strictly a personal matter.

The radical feminism claims that 'personal is political' and women oppression done by men is the fundamental one. It is possible as women - who all are good by nature - are empowered by aggressive, egoistic and physically stronger men, who are corrupted by being oppressors. Femininity as the better part of the humanity is the only hope of the endangered world. The masculinity will run out of its potential and collapse by itself if women refuse to cooperate with men - at least it is what radical feminism optimistically believes in. 
The socialist feminism considers femininity as a result of social conditions. The oppression of women is connected with the rules of a class society. Only socialistic state can help women to overcome their housework and childcare burdens. According to this ideology, gender is not a biological phenomenon. It is a changeable construct. Also sex can be interpreted in different ways as associated with family, a procreation, a sin or as an independent category of experience depending on the socially accepted customs.

The feminism of power demands the real participation of women in the structure of power though admitting that most women need men in their social and private lives. Women are neither better nor worse - they are equal to men and that is why they should have the same rights. They should not be afraid, stop complaining and start attacking their oppressors. The real change is possible and the single obstacle is the mentality of women who want to believe that their only power is to be weak.

The cultural feminism is similar to the radical one in its view on men and women relationships. It claims that there are big differences between sexes. They are connected with biology and society. Motherhood and menstruation as typically feminine experiences make women more sensitive and close to the nature. They make women response by care, submission and even love to the aggression of patriarchy, which rules in culture, science and language. The masculinity of language keeps women silent even when they try to talk or are allowed to talk. It is why there is a strong need to create a women's language that would be more dual, dialogical, emphatic and warm than the individualistic and cold language of men.

Although cultural feminists believe in differences between men and women, they also postulate the need of abolishing the gendered perception. They want to get rid of the socialization and of the social rules that are sex oriented. It wouldn't eliminate the fact that the binary differences exist but it would be a chance for a development of authentic femininity - they claim.

The points of view on the existence of male-female differences vary in particular feminist approaches but the wish to treat gender as an invisible category is similar for many of them. Some do not believe in any differences. Others believe that there is a natural difference in favor of women - as they all are better than men. In the latter case, the reduction of the difference gives better chances to women to take the power over.

The evolution of the language - gender relation and its implications for linguistic studies could be observed in the papers edited by J. Coates in the Reader (1996). According to her, the first researchers were focused on the analysis of phonetic, phonemic, morphological, and syntactic characteristics of the male and female talk. Later, their interests were concentrated on conversational strategies of mixed groups and, the finally same sex discussion participants were observed. The essentialist approach and the quantitative methods dominated the 60s and the 70s. Class and age differences were studied and only then sex appeared as relevant and was examined more carefully. In the next period, i.e. in the $70 \mathrm{~s}$ and the $80 \mathrm{~s}$, the cultural aspects of gender began to become important together with the preference to use qualitative methods. In the last years of the 20th century social constructionism allowed to combine quantitative and qualitative methods. Authors not only described male and female languages but also tried to find an explanation of their characteristics using such terms as covert prestige, social and inter group relations, economic factors or the needs of linguistic market. Conversational strategies such as politeness, comments, apologies, orders, swearing, silencing, interruptions or introductions of new subjects were analyzed leading to the conclusion of different communicative competence developed by men and women using separate conversational styles.

The theoretical debates deal with the problems of power, difference and dominance in case of gender issues. The researches try to answer the question how strongly women language is related to the language of low status persons - irrespective of sex. Among others, the court witnesses' speech was analyzed with the focus on the language used by people of different social status (O'Barr \& Atkins 1998). It occurred that to solve the problem one needs to take into consideration multifunctional nature of linguistic forms and their culture specific character (for example, the strong, assertive, direct forms considered male in the European culture are seen as childish and immature in the Japanese one). However, in some research gender seemed to influence social linguistic behavior stronger then the status did. When the doctor-patient relations were analyzed, 


\section{Dorota Brzozowska: The Role of Gender in Lanugage Communication...}

the doctors were usually interrupting more unless the doctors were women and then they were interrupted equally often by their patients (West 1998).

The expectations towards the language of people with high status are contrary to the society expectations towards women. Those who hold public functions are expected to use the male conversational style, but when they do, they are called aggressive, unfeminine and blamed for seeking confrontation. Women choose different ways of approaching this problem in maledominated workplaces. Some - as policewomen (McElhinny 1998) - accept the male way of behavior and others - e. g. female academics (Nelson 1998) - use more cooperative strategies focusing on 'productive conflict' from which everyone benefits making all group members the winners. It seems that women, who have some autonomy, are able to use their international patterns to achieve good effects and in this case gender is not in conflict with status but in most workplaces women have to adopt male patterns. The situation usually causes many difficulties in women's lives.

The next question researchers deal with is the reason of the difference. Is it the reflection of the dominance relations or different socialization patterns that make boys and girls grown up in separate subcultures? The dominance models were criticized by feminist activists for showing women as weak or victims and their language as the variation of a norm (understood as a male language). The advantage of the model of difference (developed by Deborah Tannen 1995) is showing the positive aspects of women language and its usefulness to same sex conversational analysis. The difference model treats all the cross-sex misunderstandings as problems caused by cultural differences. Separate expectations that speakers have at the beginning of a conversation are the other reasons of miscommunication.

The theoretical debates influence the methods used in linguistic analysis. According to the postulated trends, the method of observation - called ethnography - is considered useful. Conversational analysis should be done by people from inside - researchers are participants themselves and all the participants' voices are taken into account while forming the interpretations and conclusions on what had really happened during the conversation. It is why the interviews with participants become an integral part of the language analysis.

The tendency to explore the same sex talk is well illustrated by Jenniffer Coats' book, Women Talk: Conversation between Women Friends (1996). Once again, the strongly cooperative character and the dominance of a 'group voice' upon an individual one appears in the female talk. Positive encouragements, overlapping of discourses and co-construction of statements are shown as different from the male lack of support, silence, monologs and direct disagreements. The ethnographic method is used in the study and the participants' comments recorded in the interviews become a part of the analysis.

Women underline the value and the importance of talk for 'doing' their friendships, whereas physical activities are the starting points for male friendships, as it is shown in the paper on the cooperative verbal behavior of sport teams' participants (Cameron 1989). The rituals of protecting and degrading 'face' were analyzed as the two sides of language politeness. It was interpreted as the male strategy of showing solidarity. One of the male language characteristics is the need to underline not only masculinity but also heterosexuality in friends talk, as to become a man, a boy has to go through the triple negation - that he is not a women, not a child and not a gay (Badiner 1993). More detailed analysis of the male conversations could be found in Language and Masculinity (1997) book. The conclusion drawn from comparison is that the male and female friends have the same aim of their talk - to show solidarity - but the strategies they use differ for both sexes.

The two main ideologies that influenced the idea of 'doing gender' that come from outside the linguistics are postmodernism and identity politics ${ }^{1}$. Although theoretically different, practically they are both antiessentialist movements. Essentialists believe in natural differences between sexes, declaring that women have something in common that makes them different from men.

\footnotetext{
1) This part of the paper is based on D. Cameron's lecture presented at the 'Language, Gender, and Society' course organized by CEU in Budapest 2001.
} 
Postmodernists reject grand narratives (general stories of the world) that try to explain everything with a single theory (e.g. global differences in language) and claim that researchers should think more 'locally' about more specific phenomena. They should stop generalizing and start taking more particular contexts into consideration.

'Gender' - understood as social construction - is seen from postmodernist point of view as performative and unfinished - it means it is constructed each time speaker speaks. The idea was popularized by philosophy of J. Butler (1990) opposing and arising critique of previous researches (as works of Lakoff or Tannen) that assumed preexisting differences. According to Butler, also an identity is seen as an unstable illusion. The claim that an individual is constructed only by discourses makes the decisions and choices about one's identity impossible. It means that one doesn't have any possibilities to control the ways of shaping one's identity.

Identity politics underlines the statement that people have identities depending on their local communities. So the notion of 'the community of practice' understood as a group of people that come together around a mutual engagement in the same common endeavor - plays an important role in this type of research (Eckert, McConnell-Ginet 1995: 95).

Performativity theory provides a theoretical framework to the queer theory. It claims that gender cannot be taken for granted - as in the case of the telephone sex workers who can perform different types of gender depending on their customer's preferences (Hall 1998). The first assumptions of queer studies treated homosexuality as deviance worth exploring to underline the features of the heterosexual norm. It was assumed that homosexual couples were mirroring the heterosexual model (the reconstruction can be observed in opposition of butch - femme roles in lesbian relationship). The further investigation (for example among transgendered travesty) made researchers think about more complicated explanations of reality. As some of the feminist ideologies tried to challenge the 'compulsory heterosexuality', the queer theory opposes 'heteronormativity'. Both tendencies are blamed for enforcing the need of constructing oneself in the way that you become desirable by others. The supporters of this ideas maintain that you can be more powerful if you don't have to care about being attractive. According to them, for example being a lesbian makes you less powerless. The claim does not seem to be true as it may only change the object of your desire not its nature or mechanisms.

All the discussed ideologies are under the influence of the globalization trend. The widespread information technology, the use of English as an international language and the strong Americanization of culture make certain ideologies spread all over the world and gain the status of 'global truths'. The 'gender studies' itself illustrates this trend very well. Some years ago it was present only at a few American universities and a couple of years later it is consider almost 'compulsory' also at many European, Asian or Australian universities. Amazingly researchers working on different continents use the same sources and publications as a starting point of their own studies (usually called gender as even the term is rarely translated). The situation makes the return to global point of view inescapable.

The problem with the category of gender as a construct is that though it is very useful for feminism, it makes feminism redundant (Melosik 1996). If its aim is to fight for women's rights and there are no women - as this category is only a social construct - there is no basis for feminism to exist and no point of 'women studies' to promote feminine culture, literature or science. Speaking 'in the name of women' makes then no sense at all. On one hand, feminism often rejects biology as a source of femininity and masculinity but on the other hand it fights for women rights. This attitude presupposes the existence of this category and enforces essentialism. In this way, the vicious circle is created.

Although many different attempt were made to deny it, the binarism is still a very important way of constructing gender since no third category was discovered as queerness is a borderline form moving on the margins of the prototypical male-female division. You may be free to choose how you speak but you cannot make people understand what you want and how they perceive you. So you are unable to change the situation of binary perception. Let me illustrate it with a real life situation. During the first meeting of the 'Language, Gender, and Society' course participants, an experienced and a very conscious of gender problems lecturer could not resist saying: 'Welcome 
all, oh, I see that there are many women and only a couple of men in our group'. The reaction of one of the men was symptomatic: 'What makes you think so?'

There was no verbalized answer - and no wonder as it could be very difficult to explain how it happens - nevertheless the binary classification usually is done automatically as an obvious and natural one. It seems that those who want to disapprove the existence of differences have still a lot to do as there is no other evidence for the lack of the difference except for the philosophical speculations.

\section{References}

Badinter, E. 1992. XY tożsamość mężczyzny, transl. Grzegorz Przewłocki, Warszawa: WAB.

Butler, J. 1990. Gender Trouble: Feminism and the Subversion of Identity. New York: Routledge.

Cameron, D.1992. Feminism and Linguistic Theory, Macmillan.

Cameron, D. 1995. Verbal Hygiene, Routledge.

Coates, J. 1993. Women, Men and Language, Longman.

Coates, J. 1996. Women Talk: Conversation Between Women Friends, Blackwell.

Coates, J. 1998. Language and Gender: A Reader. London: Blackwell.

Eckert, P. \& McConnell Ginet S. 1995. Constructing Meaning, Constructing Selves: Snapshots of Language, Gender and Class from Belten High. In: Hall and Bucholtz (Eds.) Gender Articulated: Language and the Socially Constructed Self. London: Routledge, pp. 469-508.

Elgin, S. H. 1993, Genderspeak, Men, Women, and the Gentle Art of Verbal Self-Defense, John Wiley \& Sons.

Hall, K. \& O'Donovan, V. 1997. Shifting Gender Positions among Hindi-speaking Hijras. In: Bergvall, Victoria, et al, (Eds.) Rethinking Language and Gender Research: Theory and Practice. London: Longman.

Handke, K. 1995, Polski język familijny. Opis zjawiska, SOW.

Johnson, S. \& Meinhof, U.-H. (Eds.) 1997. Language and Masculinity. Oxford: Blackwell.

Lakoff, R. 1975. Language and woman's place, Harper \& Row Publishers.

Thorne, B., Henley Rowley, N. (Ed.) 1975. Language and Sex: Difference and Dominance. Newbury House.

McElhinny, B. 1995. Challenging Hegemonic Masculinities: Female and Male Police Officers Handling Domestic Violence. In: Hall and Bucholtz (Eds.) Gender Articulated: Language and the Socially Constructed Self. London: Routledge, pp. 217-244.

Melosik, Z. 1996. Tożsamość, ciało i władza. Poznań-Toruń: Edytor.

Mills, S. 1995. Feminist Stylistics, Routledge.

Nelson, M.W. 1998. Women's Ways : "Interactive Patterns in Predominantly Female Research Teams". In: Coates, J. 1998. Language and Gender: A Reader. London: Blackwell, pp. 354373.

O’Barr W. M. \& Atkins B. K. 1998. “'Women's Language' or 'Powerless Language'?” In: Coates J. 1998. Language and Gender: A Reader. London: Blackwell, pp. 377-388.

Tannen, D. 1995, Ty nic nie rozumiesz! Kobieta i mężczyzna w rozmowie, tłum. A. Sylwanowicz WAB.

Ślęczka, K. 1999. Feminizm. Ideologie i koncepcje spoteczne wspótczesnego feminizmu. Katowice: Wydawnictwo Książnica.

Cameron, D. (Ed.) 1998. The Feminist Critique of Language: A Reader. Routledge.

West, C. 1998. When the Doctor is a 'Lady': Power, Status and Gender in Physician-Patient Encounters". In: Coates J. 1998. Language and Gender: A Reader. London: Blackwell, pp. 396413. 